\title{
Kinetics of Serum $\beta$-D-Glucan after Pneumocystis Pneumonia Treatment in Patients with AIDS
}

\author{
Michiko Koga ${ }^{1}$, Tomohiko Koibuchi ${ }^{2}$, Tadashi Kikuchi ${ }^{3}$, Hitomi Nakamura ${ }^{1}$, \\ Toshiyuki Miura ${ }^{3}$, Aikichi Iwamoto ${ }^{1-3}$ and Takeshi Fujii ${ }^{2}$
}

\begin{abstract}
Objective Serum $\beta$-D-glucan has been demonstrated as a reliable, adjunct diagnostic marker for PCP, but its kinetics after PCP treatment are poorly understood. To evaluate the correlation between the levels of $\beta$-Dglucan and the clinical response, we investigated the individual transition of serum $\beta$-D-glucan levels after the initiation of PCP treatment.

Methods Retrospective study

Patients Seventeen PCP patients with AIDS who were admitted to our hospital were analyzed.

Results All subjects showed the serum $\beta$-D-glucan levels above the cut-off value, and the median level was $224 \mathrm{pg} / \mathrm{mL}$ [IQR: 78-597] at the time of PCP diagnosis. There were no correlations between serum $\beta$-Dglucan levels and CRP, $\mathrm{LDH}$, or $\mathrm{AaDO}_{2}$ at room air. Although there was a downward trend in serum $\beta$-Dglucan level as PCP treatment was initiated, a significant number of subjects showed a marked increase in the serum $\beta$-D-glucan levels despite their evident clinical improvement.

Conclusion The serum $\beta$-D-glucan level does not reflect the severity and prognosis of PCP infection, and thus it may not be suitable for monitoring the response to treatment.
\end{abstract}

Key words: Pneumocystis pneumonia, Pneumocystis jirovecii, $\beta$-D-glucan, HIV, acquired immune deficiency syndrome

(Intern Med 50: 1397-1401, 2011)

(DOI: 10.2169/internalmedicine.50.5296)

\section{Introduction}

Pneumocystis pneumonia (PCP), caused by Pneumocystis jirovecii ( $P$. jirovecii), is one of the most prevalent opportunistic infections among individuals with impaired immunity, particularly in patients with acquired immune deficiency syndrome (AIDS) (1-3). Since PCP is associated with significant morbidity and mortality in these immunocompromised hosts, an early diagnosis and treatment is of vital importance. The diagnosis of PCP requires microscopical examination in order to identify the characteristic morphologies of trophozoites or cysts in sputum, bronchoalveolar lavage fluid (BALF), or lung tissue, because $P$. jirovecii cannot be readily cultured (1). The sensitivity of microscopy varies according to the staining technique and the type of sample. The use of the polymerase chain reaction (PCR) to detect $P$. jirovecii nucleic acids from respiratory secretion is highly sensitive but cannot distinguish colonization from infection. Therefore, the positive results of PCR in P. jirovecii should be interpreted carefully $(4,5)$. Furthermore, these examinations generally rely on invasive diagnostic techniques, such as bronchoscopy, which is not always feasible for patients with severe respiratory distress. The measurement of serum $\beta$-D-glucan, a major cell wall component of various pathogenic fungi including $P$. jirovecii, has been demonstrated as a reliable noninvasive adjunct marker for PCP (6-12). We have also reported that all but one of the twenty-eight PCP patients with AIDS showed serum $\beta$-D-glucan levels higher than the cutoff value (13). At this stage, the kinetics of se-

\footnotetext{
${ }^{1}$ International Research Center for Infectious Diseases, the Institute of Medical Science, the University of Tokyo, Japan, ${ }^{2}$ Department of Infectious Diseases and Applied Immunology, Research Hospital of the Institute of Medical Science, The University of Tokyo, Japan and ${ }^{3}$ Division of Infectious Diseases, Advanced Clinical Research Center, The Institute of Medical Science, The University of Tokyo, Japan

Received for publication February 8, 2011; Accepted for publication March 23, 2011

Correspondence to Dr. Takeshi Fujii, tmks@ims.u-tokyo.ac.jp
} 
Table 1. The Demographics and Laboratory Data on Admission of 17 PCP Patients with AIDS

\begin{tabular}{|c|c|c|c|c|c|c|c|c|c|c|c|}
\hline Patient & Sex & Age & $\begin{array}{c}\beta \text {-D-glucan } \\
(\mathrm{pg} / \mathrm{mL})\end{array}$ & $\begin{array}{c}\mathrm{CD}_{4} \\
\left(\mathrm{cells} / \mathrm{mm}^{3}\right)\end{array}$ & $\begin{array}{l}\text { HIV-RNA } \\
\text { (copies/mL) }\end{array}$ & $\begin{array}{c}\text { WBC } \\
\left(\text { cells } / \mathrm{mm}^{3} \text { ) }\right.\end{array}$ & $\begin{array}{c}\text { Lym } \\
\text { (cells/mL) }\end{array}$ & $\begin{array}{c}\text { CRP } \\
(\mathrm{mg} / \mathrm{dL})\end{array}$ & $\begin{array}{l}\text { LDH } \\
\text { (IU/L) }\end{array}$ & $\begin{array}{c}\mathrm{PaO}_{2} \\
(\mathrm{mmHg})\end{array}$ & $\begin{array}{l}\mathrm{AaDO}_{2} \\
(\mathrm{mmHg})\end{array}$ \\
\hline 1 & Male & 25 & 40 & 35 & 240,000 & 4,660 & 419 & 4.7 & 574 & 57.7 & 46.6 \\
\hline 2 & Male & 34 & 41 & 17 & 42,000 & 6,630 & 995 & 4.5 & 339 & 62.5 & 54.0 \\
\hline 3 & Male & 46 & 43 & 8 & 120,000 & 8,030 & 522 & 10.3 & 484 & 61.7 & 51.7 \\
\hline 4 & Male & 28 & 70 & 81 & 210,000 & 5,220 & 710 & 0.8 & 348 & 80.6 & 18.0 \\
\hline 5 & Male & 29 & 78 & 26 & 29,000 & 5,960 & 1,013 & 1.4 & 360 & NT & NT \\
\hline 6 & Female & 41 & 87 & 34 & 570,000 & 4,790 & 1,418 & 2.0 & 293 & 82.2 & 20.9 \\
\hline 7 & Male & 37 & 88 & 25 & 150,000 & 3,270 & 536 & 6.0 & 399 & 70.5 & 24.0 \\
\hline 8 & Male & 54 & 108 & 7 & 88,000 & 9,970 & 399 & 19.0 & 254 & NT & NT \\
\hline 9 & Male & 28 & 224 & 33 & 43,000 & 5,890 & 501 & 8.5 & 280 & 79.6 & 30.2 \\
\hline 10 & Male & 49 & 247 & 115 & 890,000 & 13,480 & 1,011 & 0.7 & 487 & 44.1 & 70.0 \\
\hline 11 & Male & 55 & 314 & 28 & 64,000 & 4,600 & 879 & 6.1 & 570 & 70.3 & 40.0 \\
\hline 12 & Male & 40 & 335 & 22 & 180,000 & 2,830 & 979 & 4.0 & 316 & 57.5 & 49.9 \\
\hline 13 & Male & 32 & 597 & 29 & 90,000 & 5,760 & 778 & 2.4 & 396 & 79.9 & 24.5 \\
\hline 14 & Male & 36 & 634 & 37 & 43,000 & 4,080 & 918 & 8.9 & 389 & 44.9 & 64.5 \\
\hline 15 & Male & 55 & 913 & 17 & 100,000 & 8,650 & 519 & 9.7 & 442 & 39.1 & 66.4 \\
\hline 16 & Male & 61 & 1,650 & 69 & 310,000 & 7,800 & 1,404 & 2.9 & 153 & 92.9 & 12.6 \\
\hline 17 & Male & 39 & 2,620 & 33 & 430,000 & 11,000 & 330 & 1.8 & 292 & 68.8 & 43.8 \\
\hline median & & 39 & 224 & 29 & 120,000 & 5,890 & 778 & 4.5 & 360 & 68.8 & 43.8 \\
\hline
\end{tabular}

rum $\beta$-D-glucan after PCP treatment is poorly understood. Recently some reports have indicated that decreasing levels of $\beta$-D-glucan correspond to a favorable response to treatment, whereas increasing levels are associated with treatment failure $(9,11,14,15)$. On the other hand, others have stated that the serum $\beta$-D-glucan levels do not always reflect the effectiveness of therapy and are not suitable for monitoring response to treatment $(6,7)$. To evaluate the correlation between the levels of $\beta$-D-glucan and clinical response, we investigated 17 patients with AIDS who were diagnosed with PCP and analyzed their serum $\beta$-D glucan levels longitudinally after the initiation of treatment.

\section{Materials and Methods}

\section{Patients}

We retrospectively reviewed the medical records of all PCP patients with AIDS admitted in our hospital from September 2003 to July 2008, and analyzed 17 subjects who had undergone $\beta$-D-glucan assays at the diagnosis of PCP and at 2 weeks $(n=15), 4$ weeks $(n=10)$, and 6 to 12 weeks $(n=17)$ after the initiation of treatment. The diagnosis of PCP was established by microscopic identification using standard staining (Diff-Quik, Giemsa or Grocott staining) of P. jirovecii in BALF $(\mathrm{n}=16)$ or induced sputum $(\mathrm{n}=1)$. The presence of other concurrent or incident invasive fungal infections was excluded. Written informed consent was obtained from all of the participants, and the study was approved by the Institutional Review Boards of the Institute of Medical Science at the University of Tokyo. The following data were collected; sex, age, $\mathrm{CD} 4^{+}$cell counts, HIV-RNA, white blood cell (WBC) counts, lymphocyte counts, serum levels of C-reactive protein (CRP), lactate dehydrogenase (LDH), $\beta$-D-glucan, and $\mathrm{PaO}_{2}$, alveolar-arterial oxygen ten- sion $\left(\mathrm{AaDO}_{2}\right)$. We measured the serum $\beta$-D-glucan levels using $\beta$-D-glucan Wako test (Wako Pure Chemical Industries, Osaka, Japan). All patients received PCP treatment with one of the following: Trimethoprim-sulfamethoxazole (TMPSMX), Atovaquone or Pentamidine, for the total of three weeks and PCP infection improved. Adjunctive corticosteroids were given to 11 patients who had hypoxia defined by room air $\mathrm{PaO}_{2}<70 \mathrm{mmHg}$ or $\mathrm{AaDO}_{2}>35 \mathrm{mmHg}$.

\section{Statistical analyses}

Data were expressed as means \pm standard deviations (SDs) or medians \pm inter quartile range (IQRs). The relationships were analyzed by Spearman's rank correlation. The differences were considered significant at $\mathrm{p}<0.05$. Statistical analyses were performed using Graph Pad Plism 5 and JMP 8.

\section{Results}

The patient demographics and laboratory data on admission of 17 PCP patients with AIDS are shown in Table 1. Of these patients, 13 also had oral and/or esophageal candidiasis (except pt. \#1, \#11, \#13 and \#14). Other complicated opportunistic infectious diseases were cytomegalovirus (CMV) esophagitis (pt. \#2), CMV colitis (pt. \#9), toxoplasmic encephalitis (pt. \#3), and atypical mycobacteriosis (pt. \#7). All patients were men except for patient No.6. None was taking antiretroviral therapy (ART) at the diagnosis of PCP. The mean age was 41 years old, and the median of $\mathrm{CD}^{+}$cell counts was 29 [Inter quartile range (IQR): 22-35] cells $/ \mu \mathrm{L}$ and that of HIV-RNA was $1.2 \times 10^{5}$ [IQR: $6.4 \times 10^{4}$ $\left.2.4 \times 10^{5}\right]$ copies $/ \mathrm{mL}$. Although values were diverse, ranging from 40 to $2,620 \mathrm{pg} / \mathrm{mL}, \beta$-D-glucan levels in all of the subjects were above the manufacturer's cut-off value of 11 $\mathrm{pg} / \mathrm{mL}$, and the median was $224 \mathrm{pg} / \mathrm{mL}$ [IQR: 78-597]. 
(a)

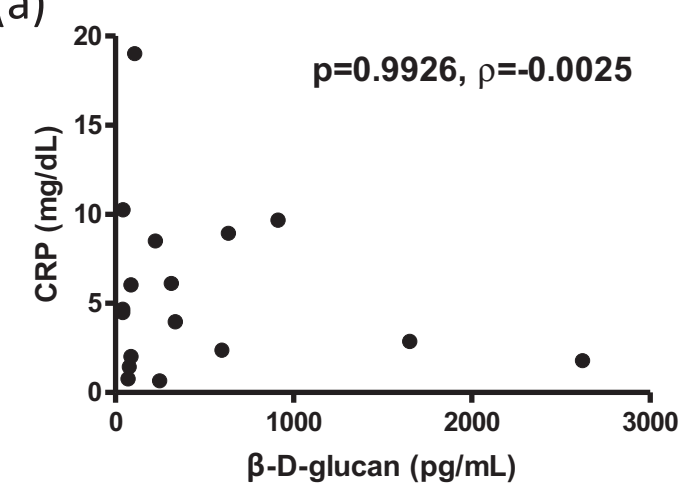

(b)

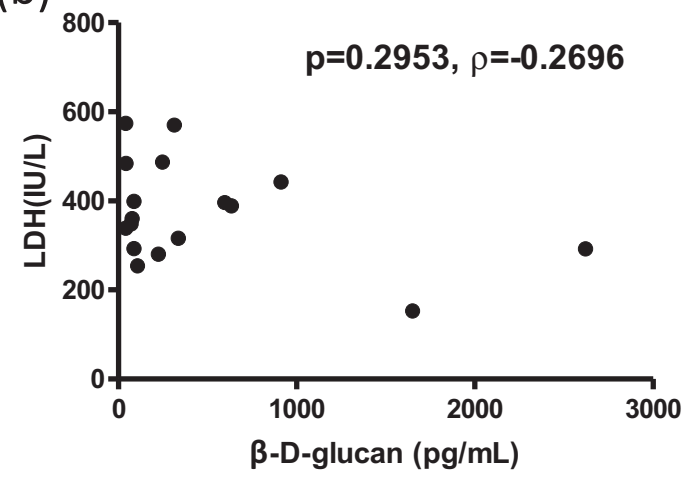

(c)

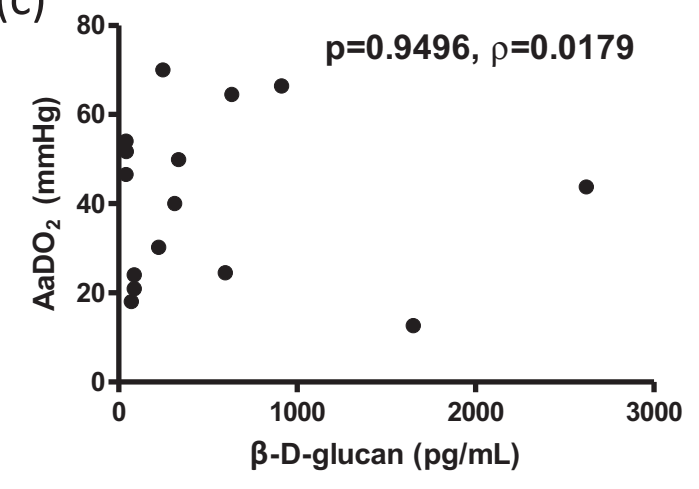

Figure 1. The correlations between three clinical markers [(a) CRP, (b) $\mathrm{LDH}$, (c) $\mathrm{AaDO}_{2}$ ] and serum $\beta$-D-glucan levels. Serum $\beta$-D-glucan levels did not correlate with the three clinical markers.

There were no correlations between serum $\beta$-D-glucan levels before PCP treatment and $\mathrm{CD}^{+}$cell counts $(\rho=0.1632$; $p=$ $0.5314)$, HIV-RNA $(\rho=0.1508 ; p=0.5634)$, CRP $(\rho=-0.0025$; $\mathrm{p}=0.9926)$, $\mathrm{LDH}(\rho=-0.2696 ; \mathrm{p}=0.2953), \mathrm{PaO}_{2}$ at room air $(\rho=-0.0571 ; p=0.8397), \mathrm{AaDO}_{2}$ at room air $(\rho=0.0179 ; \mathrm{p}=$ 0.9496) (Fig. 1). All patients accomplished 3 weeks treatment of PCP, and all of their clinical manifestation and the radiographic findings steadily improved. Their median value of CRP and LDH decreased significantly after 3 weeks from $4.49 \mathrm{mg} / \mathrm{dL}$ to $0.64 \mathrm{mg} / \mathrm{dL}(\mathrm{p}<0.0001)$ and from $360 \mathrm{IU} / \mathrm{L}$ to $181 \mathrm{IU} / \mathrm{L}(\mathrm{p}<0.0001)$, respectively. We further assessed the kinetics of serum $\beta$-D-glucan levels of each subject after initiating treatment of PCP until 6 weeks later (Fig. 2). The serum $\beta$-D-glucan values dropped to within normal range
$(<11 \mathrm{pg} / \mathrm{mL})$ in only 3 of 17 patients $(17.6 \%)$ at the completion of PCP treatment in 4 weeks, and in 7 of 17 (41\%) even at 6 weeks. Overall, the serum $\beta$-D-glucan levels seemed to have decreased as the PCP treatment began. However, $\beta$-D-glucan levels slightly increased in some individuals at 2 weeks (pt. \#3: 43 to $132 \mathrm{pg} / \mathrm{mL}$, \#4: 70 to 102 $\mathrm{pg} / \mathrm{mL}$, \#5: 78 to $180 \mathrm{pg} / \mathrm{mL} \# 7$ : 88 to $98 \mathrm{pg} / \mathrm{mL}$ ) and at 4 weeks (pt. \#7: 98 to $120 \mathrm{pg} / \mathrm{mL}$, \#11: 70 to $107 \mathrm{pg} / \mathrm{mL}$ ) despite their favorable responses to the treatment. These temporal increases came down gradually at 6 weeks. In all patients, the serum $\beta$-D-glucan levels decreased to within the normal range several months after the treatment (data not shown).

Discussion

The serum $\beta$-D-glucan has been used as a serologic marker for the diagnosis of invasive fungal infection, such as deep-seated candidiasis and aspergillosis (16-18). However, the usefulness of $\beta$-D-glucan for the diagnosis PCP has not been globally recognized. One of the reasons is that the initial validation of $\beta$-D-glucan testing in the United States did not include patients with PCP (19). Recently, a number of studies have reported correlations of elevated serum $\beta$-Dglucan with the diagnosis of PCP in patients both with and without HIV infection. Many studies have shown an excellent diagnostic performance with a sensitivity of 90-98\% and specificity of $86.1-94 \%$ using an appropriately defined cut-off value $(6,7,10,20,21)$. The positive predictive value has been reported to be $61.0-64.7 \%$, while the negative predictive value has been demonstrated to be much higher $(98.0-99.8 \%)(6,10)$. Although we cannot assess the usefulness of $\beta$-D-glucan as the diagnostic marker of PCP in this study, the excellent performance characteristics of serum $\beta$ D-glucan testing look promising for a diagnostic maker.

In the present study, we have shown that the serum $\beta$-Dglucan levels did not reflect the severity in individual cases. Thus far, studies of $\beta$-D-glucan as prognostic and follow-up makers in PCP patients have reported mixed results $(6-8,15)$. Shimizu et al $(15)$ have reported that high levels of serum $\beta$-D-glucan could be a prognostic marker associated with a worse outcome in PCP patients with connective tissue disease. Watanabe et al (7) demonstrated that there were no correlations between serum levels of $\beta$-Dglucan and $\mathrm{AaDO}_{2}$ at room air, LDH, or CRP upon examining 111 PCP patients with AIDS. Held et al (6) have also shown no significant difference in the mortality or severity of PCP with various underlying diseases between patients' with varying $\beta$-D-glucan levels. We have performed a detailed analysis of the multiple time points of serum $\beta$-Dglucan levels after the initiation of PCP treatment in 17 PCP patients with AIDS individually. At present, the kinetics of serum $\beta$-D-glucan during PCP treatment remains uncertain. Cuétara et al (9) have suggested that decreasing levels of $\beta$ D-glucan correspond with a favorable response to treatment, whereas increasing levels were associated with treatment 


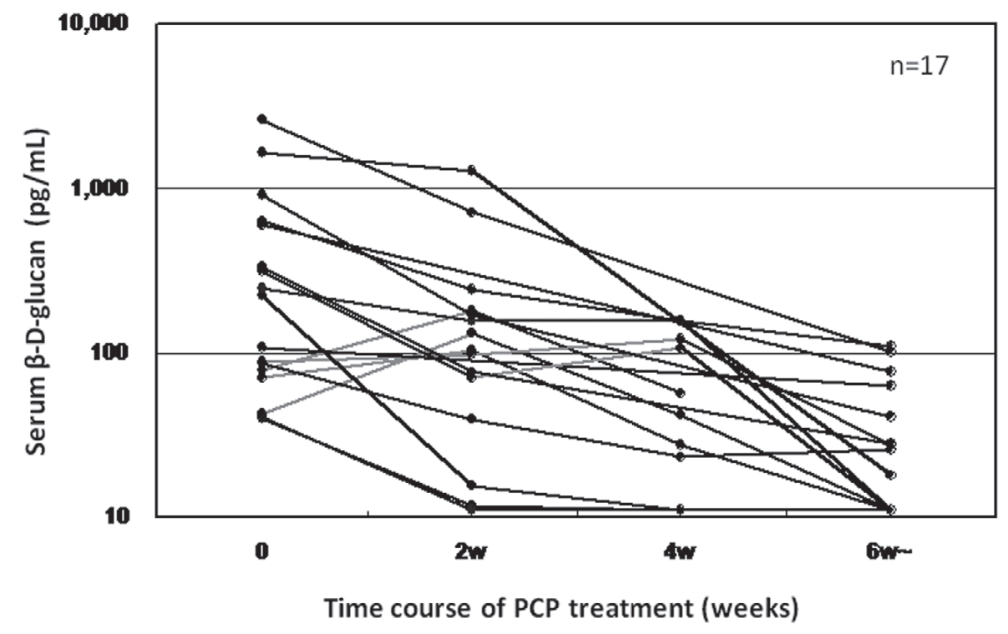

Figure 2. The kinetics of serum $\beta$-D-glucan levels of each subject after initiating treatment of PCP. There was a downward trend of serum $\beta$-D-glucan level as PCP treatment was initiated; five subjects (gray line) showed an increase in serum $\beta$-D-glucan levels despite their evident clinical improvement.

failure in 3 PCP patients with HIV infection. Recently, de Boer et al (20) have described that the median absolute value of serum $\beta$-D-glucan of $21 \mathrm{HIV}$-negative PCP patients decreased significantly at around 3 days after treatment and inversely correlated with pneumocystis PCR cycle threshold values in BAL fluid. A similar tendency has been described in several reports $(11,14)$. Although the present data have shown that the median value of serum $\beta$-D-glucan decreased from $224 \mathrm{pg} / \mathrm{mL}$ to $104 \mathrm{pg} / \mathrm{mL}(\mathrm{n}=15, \mathrm{p}<0.01)$ two weeks after treatment, the kinetics of 5 out of 17 patients were elevated temporary right after treatment despite clinical improvement. Consistent with our observation, Watanabe et al (7) revealed that $20 \%$ of patients had increased levels of $\beta$-D-glucan during the early phase of treatment despite clinical improvement being noted at week 3. Although the decreasing levels of $\beta$-D-glucan may correspond to a favorable response to treatment overall, we propose that $\beta$-D-glucan is not suitable for monitoring the response to treatment. Clinical observation prevails over the change in $\beta$-D-glucan levels when evaluating the treatment of PCP.

In conclusion, the serum $\beta$-D-glucan level does not reflect the severity and prognosis of PCP infection, and they may not be suitable for monitoring the response to treatment. In spite of low statistic power, the present study is valuable for clinicians who monitor $\beta$-D-glucan kinetics during PCP treatment. To confirm these results, prospective studies on larger cohorts of patients are necessary.

The authors state that they have no Conflict of Interest (COI).

\section{Acknowledgement}

We thank Kei Ouchi for his comments on drafts of the manuscript.

\section{References}

1. Krajicek BJ, Limper AH, Thomas CF Jr. Advances in the biology, pathogenesis and identification of Pneumocystis pneumonia. Curr Opin Pulm Med 14: 228-234, 2008.

2. Thomas CF Jr, Limper AH. Pneumocystis pneumonia. N Engl J Med 350: 2487-2498, 2004.

3. Kovacs JA, Gill VJ, Meshnick S, Masur H. New insights into transmission, diagnosis, and drug treatment of Pneumocystis carinii pneumonia. JAMA 286: 2450-2460, 2001.

4. Finkelman MA. Pneumocystis jirovecii infection: Cell wall betaD-glucan biology and diagnostic utility. Crit Rev Microbiol 36: 271-281, 2010.

5. Alvarez-Martinez MJ, Miro JM, Valls ME, et al. Sensitivity and specificity of nested and real-time PCR for the detection of Pneumocystis jiroveci in clinical specimens. Diagn Microbiol Infect Dis 56: 153-160, 2006.

6. Held J, Koch M, Reischl U, Danner T, Serr A. Serum (1-->3)beta-D-Glucan measurement as early indicator for Pneumocystis jirovecii pneumonia and evaluation of its prognostic value. Clin Microbiol Infect 17: 595-602, 2011.

7. Watanabe T, Yasuoka A, Tanuma J, et al. Serum (1-->3) beta-Dglucan as a noninvasive adjunct marker for the diagnosis of Pneumocystis pneumonia in patients with AIDS. Clin Infect Dis 49: 1128-1131, 2009.

8. Nakamura H, Tateyama M, Tasato D, et al. Clinical utility of serum beta-D-glucan and KL-6 levels in Pneumocystis jirovecii pneumonia. Intern Med 48: 195-202, 2009.

9. Cuetara MS, Alhambra A, Chaves F, Moragues MD, Ponton J, del Palacio A. Use of a serum (1-->3)-beta-D-glucan assay for diagnosis and follow-up of Pneumocystis jiroveci pneumonia. Clin Infect Dis 47: 1364-1366, 2008.

10. Tasaka S, Hasegawa N, Kobayashi S, et al. Serum indicators for the diagnosis of Pneumocystis pneumonia. Chest 131: 1173-1180, 2007.

11. Marty FM, Koo S, Bryar J, Baden LR. (1->3) beta-D-glucan assay positivity in patients with Pneumocystis (carinii) jiroveci pneumonia. Ann Intern Med 147: 70-72, 2007.

12. Yasuoka A, Tachikawa N, Shimada K, Kimura S, Oka S. (1-->3) beta-D-glucan as a quantitative serological marker for Pneumocystis carinii pneumonia. Clin Diagn Lab Immunol 3: 197-199, 1996.

13. Fujii T, Nakamura T, Iwamoto A. Pneumocystis pneumonia in pa- 
tients with HIV infection: clinical manifestations, laboratory findings, and radiological features. J Infect Chemother 13: 1-7, 2007.

14. Del Palacio A, Llenas-Garcia J, Soledad Cuetara M, et al. Serum (1-->3) beta-D-Glucan as a noninvasive adjunct marker for the diagnosis and follow-up of Pneumocystis jiroveci pneumonia in patients with HIV infection. Clin Infect Dis 50: 451-452, 2010.

15. Shimizu A, Oka H, Matsuda T, Ozaki S. (1-->3)-beta-D glucan is a diagnostic and negative prognostic marker for Pneumocystis carinii pneumonia in patients with connective tissue disease. Clin Exp Rheumatol 23: 678-680, 2005.

16. Mori S, Cho I, Ichiyasu H, Sugimoto M. Asymptomatic carriage of Pneumocystis jiroveci in elderly patients with rheumatoid arthritis in Japan: a possible association between colonization and development of Pneumocystis jiroveci pneumonia during low-dose MTX therapy. Mod Rheumatol 18: 240-246, 2008.

17. Persat F, Ranque S, Derouin F, Michel-Nguyen A, Picot S, Sulahian A. Contribution of the (1-->3)-beta-D-glucan assay for diagnosis of invasive fungal infections. J Clin Microbiol 46: 1009-
1013, 2008.

18. Obayashi T, Yoshida M, Mori $T$, et al. Plasma (1-->3)-beta-Dglucan measurement in diagnosis of invasive deep mycosis and fungal febrile episodes. Lancet 345: 17-20, 1995.

19. Ostrosky-Zeichner L, Alexander BD, Kett DH, et al. Multicenter clinical evaluation of the (1-->3) beta-D-glucan assay as an aid to diagnosis of fungal infections in humans. Clin Infect Dis 41: 654$659,2005$.

20. de Boer MG, Gelinck LB, van Zelst BD, et al. beta-d-Glucan and S-adenosylmethionine serum levels for the diagnosis of Pneumocystis pneumonia in HIV-negative patients: A prospective study. J Infect 62: 93-100, 2011.

21. Desmet S, Van Wijngaerden E, Maertens J, et al. Serum (1-3)beta-D-glucan as a tool for diagnosis of Pneumocystis jirovecii pneumonia in patients with human immunodeficiency virus infection or hematological malignancy. J Clin Microbiol 47: 38713874, 2009.

(C) 2011 The Japanese Society of Internal Medicine http://www.naika.or.jp/imindex.html 